Original Research

\title{
Studi Literatur tentang Kuantitatif Penggunaan Antibiotik pada Bangsal Bedah dengan DDD
}

\author{
Ervin Colyn ${ }^{1}$, Fauna Herawati ${ }^{1 *}$, Rika Yulia $^{1}$ \\ ${ }^{1}$ Fakultas Farmasi, Universitas Surabaya, Surabaya-Indonesia \\ * corresponding author: fauna@staff.ubaya.ac.id
}

\begin{abstract}
Antibiotic resistance is one of the healthcare problems associated with higher medical costs, prolonged hospital stays, and increased mortality rate. Monitoring antibiotic usage purposed to control the incidence of antibiotic resistance. Past research reported that there was an irrational use of surgical prophylaxis in Asia. The objective of this research is to review surgical prophylaxis utilization using DDD method with DDD/100 Bed Days as outcome. The study design used is systematic review. The articles included in this study were cross-sectional study design, in Indonesian or English language, and published between the years 2010-2020. The defined daily dose, antibiotic prophylaxis, surgery were the search term. This study assesses the quality of journals by The Joanna Briggs Institute (JBI) checklist and the journal's reputation. There were eleven articles, five articles had a good quality according to JBI checklist and published at journal indexed Scopus or accredited by National Journal Accreditation (ARJUNA) SINTA 1-3. The most used surgical prophylaxis antibiotic in 6 locations was ceftriaxone. Meanwhile, Cefazolin, the first choice surgical prophylaxis antibiotic recommended by the guideline, only reported being used the most at 2 locations. In Asia, there are irrational surgical prophylaxis antibiotic utilizations. The monitoring of surgical prophylaxis antibiotic use needs to be improved to increase the appropriateness.
\end{abstract}

Keywords: defined daily dose, antibiotic prophylaxis, surgery, asia

\begin{abstract}
Abstrak-Resistensi antibiotik merupakan salah satu masalah kesehatan karena meningkatkan biaya perawatan, memperpanjang lama rawat di rumah sakit, dan meningkatkan angka kematian. Pemantauan penggunaan antibiotik bertujuan untuk mengendalikan kejadian resistensi antibiotik. Penelitian terdahulu melaporkan bahwa masih banyak terjadi pemakaian antibiotik secara irasional di bangsal bedah di Asia. Penelitian ini bertujuan untuk mengkaji pola pemakaian antibiotik di bangsal bedah dalam satuan DDD/100 bed days. Penelitian ini merupakan kajian sistematik. Artikel terpilih dalam penelitian ini adalah artikel penelitian potong lintang, berbahasa Indonesia atau Inggris, dan dipublikasi antara tahun 2010 sampai 2020. Kata kunci yang dipakai adalah defined daily dose, antibiotic prophylaxis, surgery. Kualitas jurnal dinilai dengan checklist Joanna Briggs Institute (JBI) dan reputasi jurnal. Hasil: Didapatkan sebelas artikel, lima jurnal memiliki kualitas baik menurut checklist JBI dan dipublikasi oleh jurnal terindeks Scopus atau terakreditasi Sinta 1-3. Berdasarkan hasil sintesis, antibiotik golongan sefalosporin merupakan antibiotik yang paling sering dipakai. Seftriakson dilaporkan pada 6 lokasi sebagai antibiotik yang paling sering dipakai sebagai profilaksis pembedahan, sedangkan sefazolin, antibiotik pilihan utama yang direkomendasikan oleh pedoman terapi, hanya dilaporkan paling banyak digunakan di 2 lokasi. Di Asia, penggunaan antibiotik profilaksis di bangsal bedah masih ada yang irasional. Pemantauan penggunaan antibiotik profilaksis di bangsal bedah perlu ditingkatkan.
\end{abstract}

Kata kunci: defined daily dose, antibiotik profilaksis, bangsal bedah, asia

\section{PENDAHULUAN}

Pada saat ini, antibiotik sering diresepkan untuk penyakit infeksi. Antibiotik diresepkan karena berkhasiat untuk membunuh atau menghambat pertumbuhan bakteri. Obat golongan ini meskipun sangat bermanfaat, bisa menjadi tidak berguna jika pemakaiannya tidak hati-hati (tidak sesuai resep atau guideline) [1]. Bakteri bisa beradaptasi terhadap obat dan menjadi resisten. Resistensi bakteri ini merupakan salah satu masalah yang dihadapi tenaga kesehatan terkait dengan antibiotik. Dampak dari resistensi bisa menyebabkan masa pengobatan semakin panjang, biaya pengobatan semakin mahal, dan penyakit yang semakin parah karena bakteri tidak bisa dibunuh [2]. Guidos juga melaporkan bahwa Amerika membayar sebesar 20 triliun dolar Amerika hanya untuk kasus resistensi bakteri.

Kajian kuantitatif pada bangsal bedah ini dilakukan karena masih ada masalah mengenai jumlah antibiotik di bangsal bedah yang berlebih [3-5], yaitu penggunaan seftriakson sebanyak 53,6\% - 56\% [3,4] dan kombinasi seftriakson - metronidazol sebanyak 41,4\%. American Society of Health System Pharmacists (ASHP) dan World Health Organization (WHO) merekomendasikan sefazolin sebagai pilihan antibiotik profilaksis bedah [3,6], bukan seftriakson. Mousavi (2017) melaporkan bahwa 54,6\% pemilihan dosis tidak sesuai dengan 
pedoman terapi, sedangkan Harrison (2015) melaporkan adanya 57\% pemberian antibiotik tidak sesuai pedoman terapi, 15,5\% dari total semua peresepan menggunakan seftriakson [5,7]. Seftriakson merupakan antibiotik yang paling sering digunakan di Asia Barat dan Tengah, sedangkan kombinasi amoksisilin dan penghambat enzim merupakan antibiotik yang paling sering digunakan di Asia Timur dan Selatan [8]. Kajian sistematik ini bertujuan untuk melakukan kajian terhadap informasi yang baru dari pemakaian antibiotik di bangsal bedah dan melakukan update terhadap informasi yang ada sebelumnya, khususnya di Benua Asia yang dinyatakan dalam satuan Defined Daily Dose (DDD) per 100 bed-days.

\section{METODE}

Desain penelitian ini merupakan kajian sistematik jurnal ilmiah, laporan penelitian penggunaan antibiotik di rumah sakit, meliputi jenis antibiotik dan jumlah penggunaan antibiotik dalam satuan $\mathrm{DDD} / 100 \mathrm{BD}$, dengan desain penelitian potong lintang, yang dipublikasikan tahun 2010-2020. Pencarian terhadap informasi dilakukan secara elektronik pada bulan Maret 2020. Basis data yang digunakan untuk mencari pustaka adalah Google Scholar dan PubMed. Kata Kunci yang dipakai adalah Defined Daily Dose, Antibiotic Prophylaxis, Surgery. Kata Antibiotic Prophylaxis diganti dengan "Antibiotik Profilaksis" dan kata Surgery diganti dengan "Bangsal Bedah" untuk pencarian jurnal berbahasa Indonesia. Kata kunci tersebut digabung dengan Boolean Operators. Search term yang dipakai yaitu "Defined Daily Dose" AND "Antibiotic Prophylaxis" AND "Surgery" atau "Defined Daily Dose" AND "Antibiotik Profilaksis" AND "Bangsal Bedah".

Jurnal yang ditemukan pada basis data kemudian di-skrining berdasarkan kriteria inklusi dan eksklusi. Kriteria inklusi berupa desain studi berupa cross sectional, artikel didapat dengan kata kunci yang telah ditetapkan, artikel didapatkan dari Pubmed dan Google Scholar, artikel yang dipublikasi paling lama 10 tahun terakhir, penelitian mencantumkan data $\mathrm{DDD} / 100$ bed days (BD). Kriteria eksklusinya, artikel tidak merupakan full text, lokasi penelitian bukan di Benua Asia, artikel dengan data bedah dengan non-bedah dicampur, bahasa yang dipakai dalam artikel bukan Inggris atau Indonesia, dan artikel dengan jumlah sampel penelitian yang tidak jelas. Jurnal dipilih jika memenuhi kriteria inklusi dan eksklusi.

Jurnal terpilih kemudian diperiksa kualitasnya dengan checklist Joanna Briggs Institute (JBI) [9] dan reputasi jurnal. Jurnal dikatakan berkualitas baik jika hasil dari checklist dan reputasi sama-sama baik. Untuk checklist $J B I$, jurnal dikatakan baik jika ada minimal tujuh jawaban yes dan pertanyaan mengenai validitas outcome dijawab yes. Untuk penilaian berdasarkan kualitas jurnal, jurnal dikatakan baik jika terindeks scopus atau atau terakreditasi Sinta 1-3.

Data penelitian penggunaan antibiotik disajikan dalam dua Tabel menurut pengelompokan kualitas jurnal. Data penggunaan antibiotik di Bangsal Bedah yang merupakan hasil penelitian artikel yang dipublikasi oleh jurnal kategori kualitas baik dipresentasikan dalam Tabel yang berbeda dengan data penggunaan antibiotik di Bangsal Bedah yang merupakan hasil penelitian artikel yang dipublikasi oleh jurnal kategori kualitas kurang. Selain penggunaan antibiotik, informasi mengenai metode penelitian, subjek penelitian, intervensi, outcome diekstraksi dari artikel penelitian terpilih. Subjek penelitian dipastikan merupakan pasien bedah yang diberi antibiotik profilaksis. Data intervensi yang diekstraksi adalah jenis antibiotik dan jumlah yang dipakai. Data outcome yang diesktraksi adalah DDD/100 bed-days. Data jenis antibiotik kemudian dikelompokkan menurut golongan antibiotik. Analisis data dilakukan secara statistik deskriptif. Data penggunaan masing-masing jenis antibiotik dalam satuan $D D D / 100$ bed-days akan dibandingkan dengan jenis antibiotik lainnya dalam artikel penelitian individual dan antar-laporan hasil penelitian. 


\section{HASIL}

\section{Seleksi studi}

Artikel didapat berdasarkan pencarian sebanyak 324 dari Google Scholar dan 20 dari PubMed. Setelah itu, skrining dilakukan berdasarkan tahun publikasi, duplikasi, judul, kriteria inklusi, dan kriteria eksklusi. Delapan puluh enam jurnal ditolak karena tahun publikasi tidak sesuai kriteria, 40 jurnal ditolak karena duplikasi, dan 207 ditolak karena tidak memenuhi kriteria inklusi dan eksklusi. Setelah dilakukan skrining, terdapat 11 artikel terpilih untuk menjawab topik yang diteliti. Alur pencarian artikel disusun sesuai panduan Preferred Reporting Items for Systematic Reviews and Meta-Analyses (PRISMA) (lihat Gambar 1).
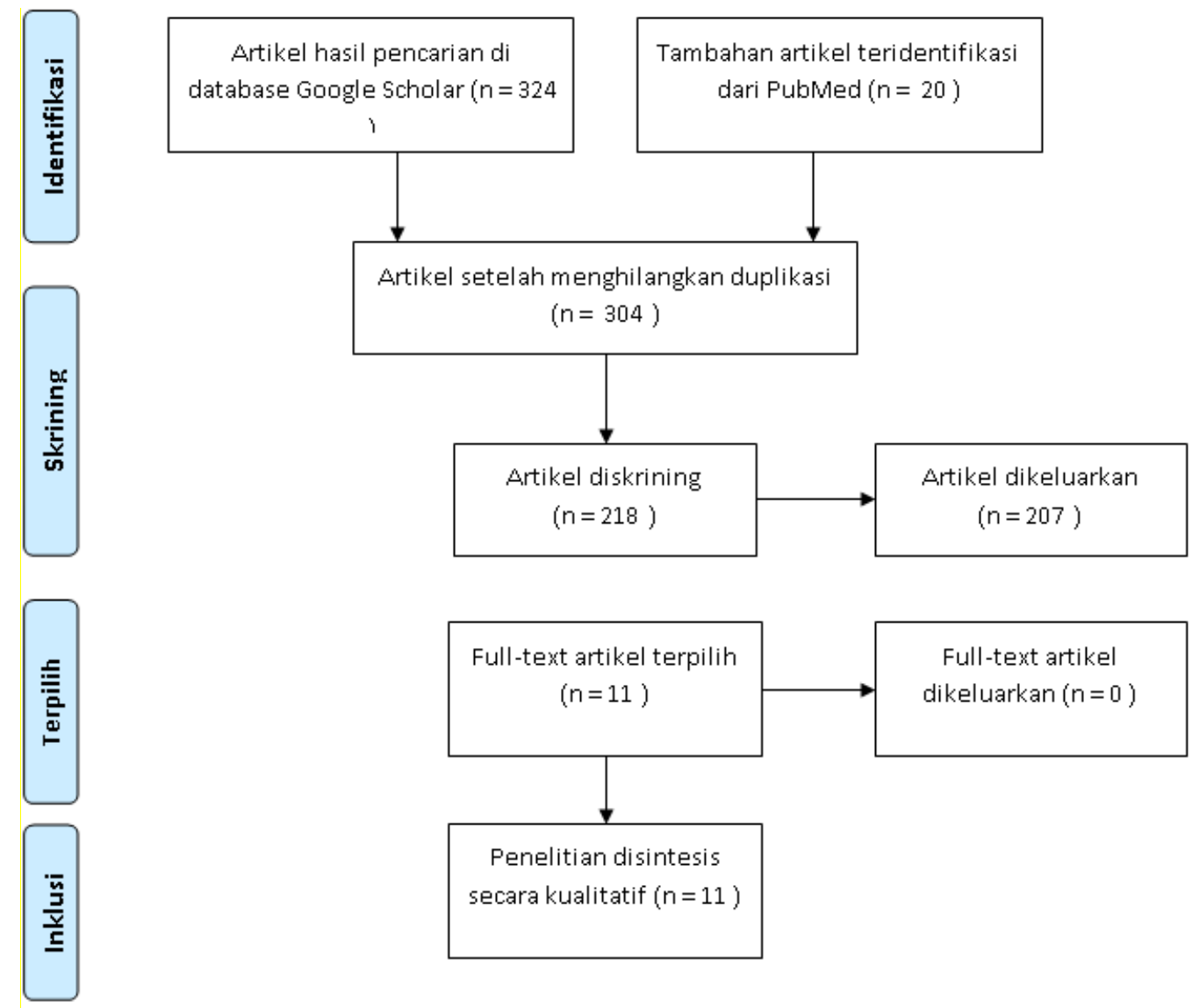

Gambar 1. Alur pencarian artikel.

\section{Kualitas Jurnal}

Pencarian artikel menghasilkan tujuh artikel terpilih (Tabel 1). Pengelompokan kualitas artikel penelitian dilakukan menurut pemenuhan kriteria pertanyaan JBI dan publikasi artikel menurut kriteria mengindeksan atau akreditasi jurnal. Artikel penelitian termasuk kategori baik jika memenuhi tujuh pertanyaan JBI (Tabel 1 ) atau dipublikasi di jurnal terindeks scopus atau terakreditasi Sinta 1-3 (Tabel 2).

\section{Tabel 1}

Karakteristik Dan Hasil Penelitian Artikel Terpilih [10-19]

\begin{tabular}{lllllll}
\hline $\begin{array}{l}\text { Nama } \\
\text { peneliti }\end{array}$ & $\begin{array}{l}\text { Tahun } \\
\text { publikasi }\end{array}$ & $\begin{array}{l}\text { Judul } \\
\text { artikel }\end{array}$ & Populasi & $\begin{array}{l}\text { Periode } \\
\text { pengumpul } \\
\text { an data }\end{array}$ & $\begin{array}{l}\text { Jumlah } \\
\text { sampel }\end{array}$ & $\begin{array}{l}\text { Hasil } \\
\text { penelitia } \\
\mathbf{n}\end{array}$ \\
\hline Waleed M. & 2012 & Utilization and & Pasien bedah & 1 bulan & 200 & Total 133,6 \\
Sweileh, SO & & cost of & di 2 rumah & & DDD $/ 100$ \\
\hline
\end{tabular}




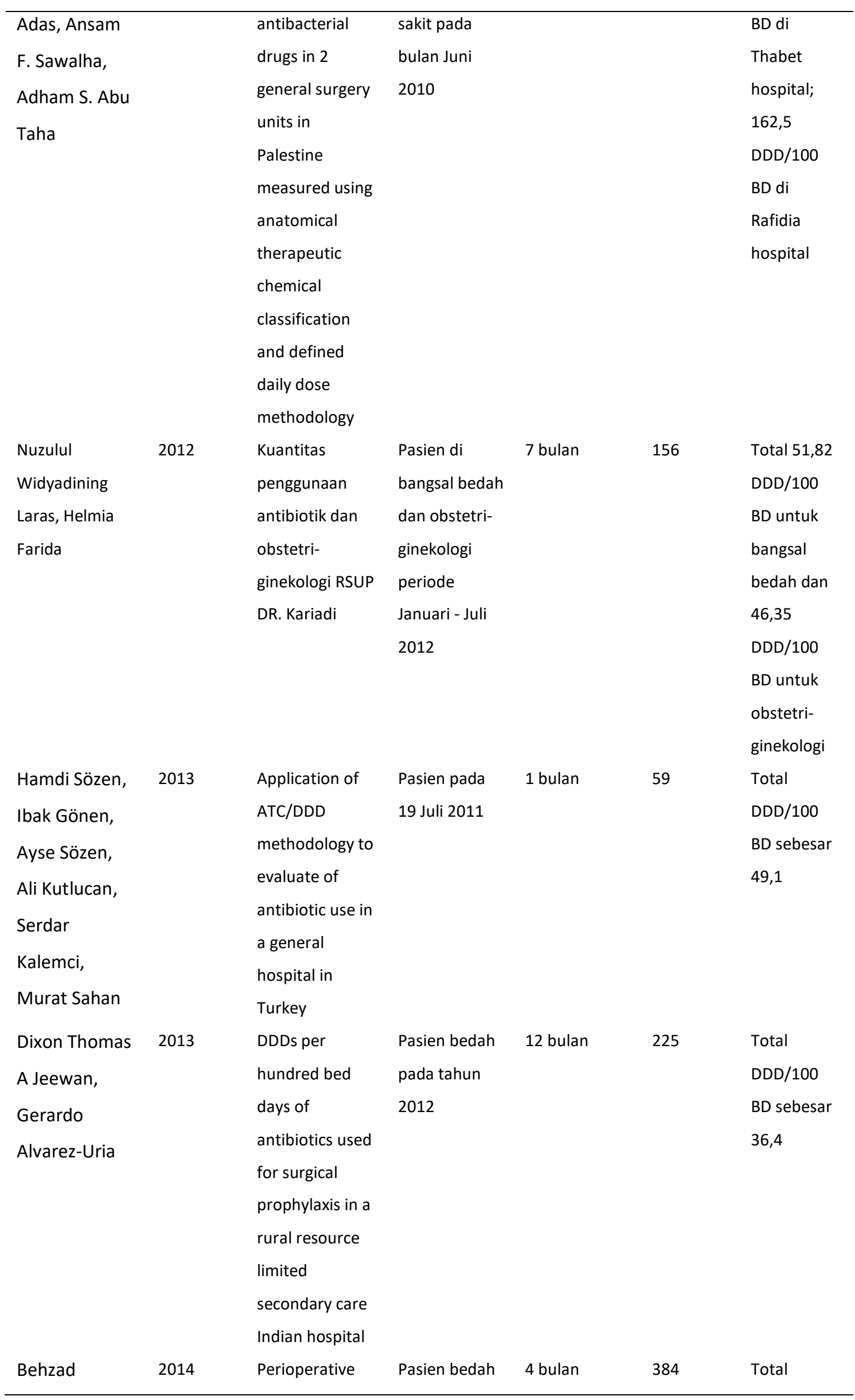




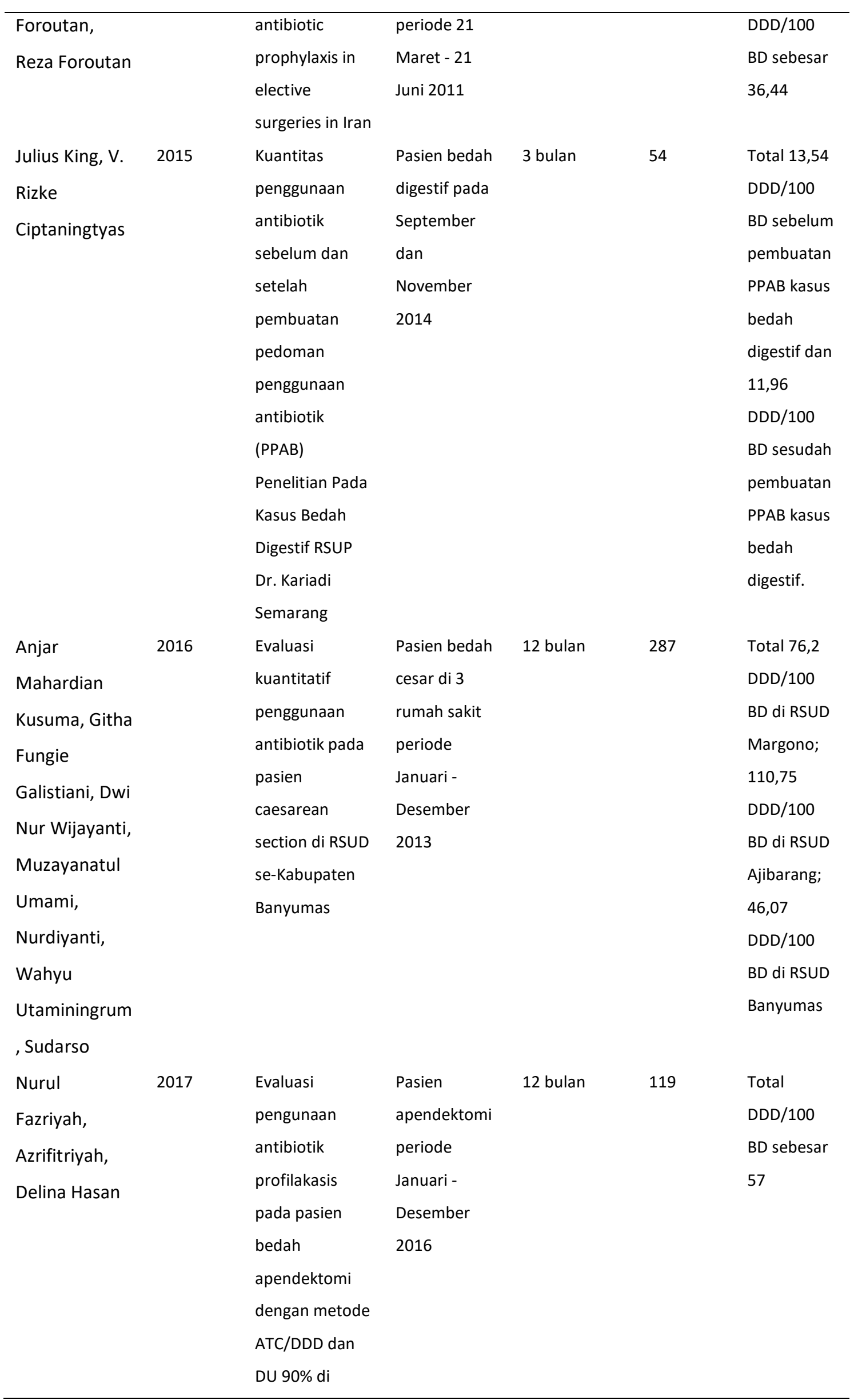




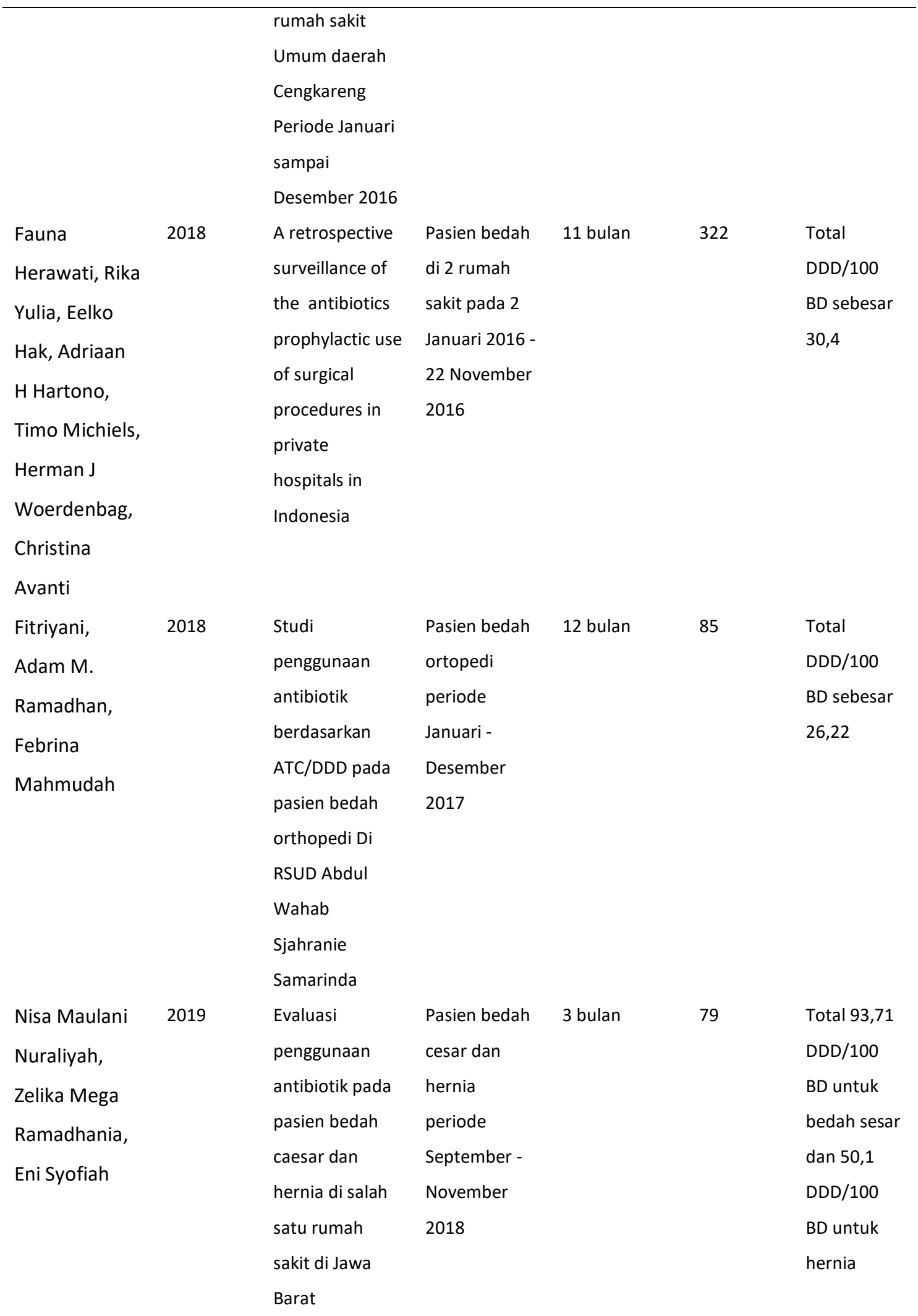




\section{Tabel 2}

Daftar Pemenuhan Kriteria Pertanyaan Joanna Briggs Institute (JBI) [10-19]

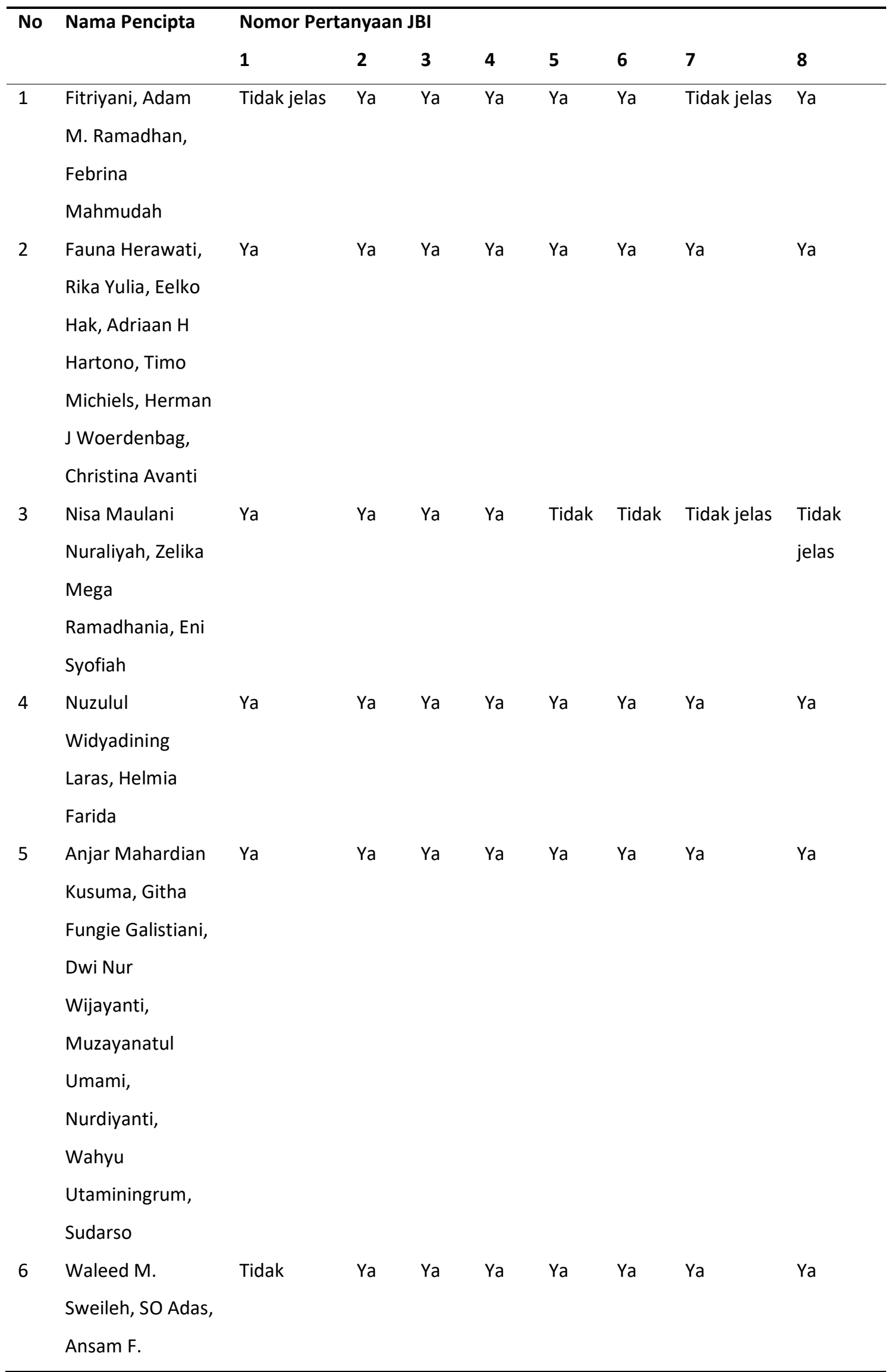




\begin{tabular}{|c|c|c|c|c|c|c|c|c|c|}
\hline & Sawalha, Adham & & & & & & & & \\
\hline & S. Abu Taha & & & & & & & & \\
\hline \multirow[t]{3}{*}{7} & Dixon Thomas A & Tidak jelas & Ya & $\mathrm{Ya}$ & $\mathrm{Ya}$ & Ya & Ya & Ya & $\mathrm{Ya}$ \\
\hline & Jeewan, Gerardo & & & & & & & & \\
\hline & Alvarez-Uria & & & & & & & & \\
\hline \multirow[t]{2}{*}{8} & Behzad Foroutan, & Ya & Ya & Ya & Ya & Ya & Ya & Ya & $\mathrm{Ya}$ \\
\hline & Reza Foroutan & & & & & & & & \\
\hline \multirow[t]{6}{*}{9} & Hamdi Sözen, & Tidak jelas & Ya & Ya & Ya & Ya & $\mathrm{Ya}$ & Ya & $\mathrm{Ya}$ \\
\hline & Ibak Gönen, Ayse & & & & & & & & \\
\hline & Sözen, Ali & & & & & & & & \\
\hline & Kutlucan, Serdar & & & & & & & & \\
\hline & Kalemci, Murat & & & & & & & & \\
\hline & Sahan & & & & & & & & \\
\hline \multirow[t]{3}{*}{10} & Nurul Fazriyah, & Ya & Ya & Ya & Ya & Ya & Ya & Ya & Ya \\
\hline & Azrifitriyah, & & & & & & & & \\
\hline & Delina Hasan & & & & & & & & \\
\hline \multirow[t]{3}{*}{11} & Julius King, V. & Ya & Ya & Ya & $\mathrm{Ya}$ & Ya & Ya & Tidak jelas & $\mathrm{Ya}$ \\
\hline & Rizke & & & & & & & & \\
\hline & Ciptaningtyas & & & & & & & & \\
\hline
\end{tabular}

\section{Tabel 3}

Daftar Artikel Penelitian Menurut Kriteria Pengindeksan Atau Akreditasi Jurnal [10-19]

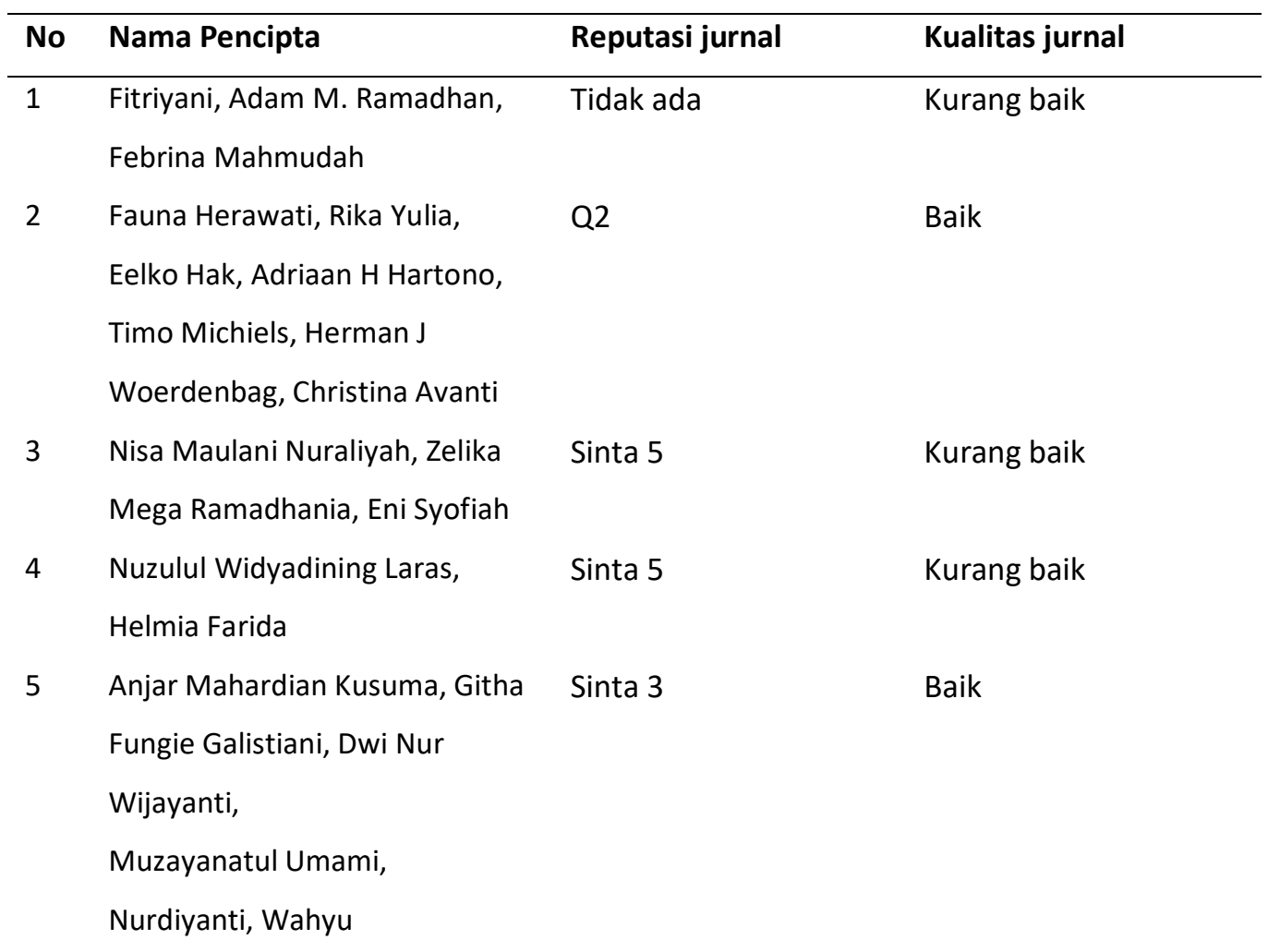




\begin{tabular}{llll}
\hline & Utaminingrum, Sudarso & & \\
6 & Waleed M. Sweileh, SO Adas, & Q3 & Baik \\
& $\begin{array}{l}\text { Ansam F. Sawalha, Adham S. } \\
\text { Abu Taha }\end{array}$ & & \\
7 & $\begin{array}{l}\text { Dixon Thomas A Jeewan, } \\
\text { Gerardo Alvarez-Uria }\end{array}$ & Tidak ada & Kurang baik \\
9 & $\begin{array}{l}\text { Behzad Foroutan, Reza Foroutan } \\
\text { Hamdi Sözen, Ibak Gönen, Ayse }\end{array}$ & Q3 & Baik \\
& $\begin{array}{l}\text { Sözen, Ali Kutlucan, Serdar } \\
\text { Kalemci, Murat Sahan }\end{array}$ & Baik \\
Nurul Fazriyah, Azrifitriyah, & Tidak ada & \\
\hline 11 & $\begin{array}{l}\text { Delina Hasan } \\
\text { Julius King, V. Rizke } \\
\text { Ciptaningtyas }\end{array}$ & Sinta 5 & Kurang baik \\
\hline
\end{tabular}

\section{Outcome DDD/100 Bed Days (BD)}

Berdasarkan data yang telah diperoleh ditemukan bahwa antibiotik golongan sefalosporin merupakan antibiotik yang paling sering digunakan sebagai profilaksis untuk pasien bedah, khususnya seftriakson. Penggunaan antibiotik sefalosporin generasi 1 , sefazolin sebesar 26,43 DDD/100 BD - 28,24 DDD/100 BD. Ada 6 Jurnal dari 11 jurnal yang melaporkan penggunaan seftriakson paling sering.

Tabel 4

Jumlah Penggunaan Antibiotik Dalam DDD/100 BD Dari Artikel Yang Dipublikasi Di Jurnal Berkualitas Baik $[4,10,12,14,16]$

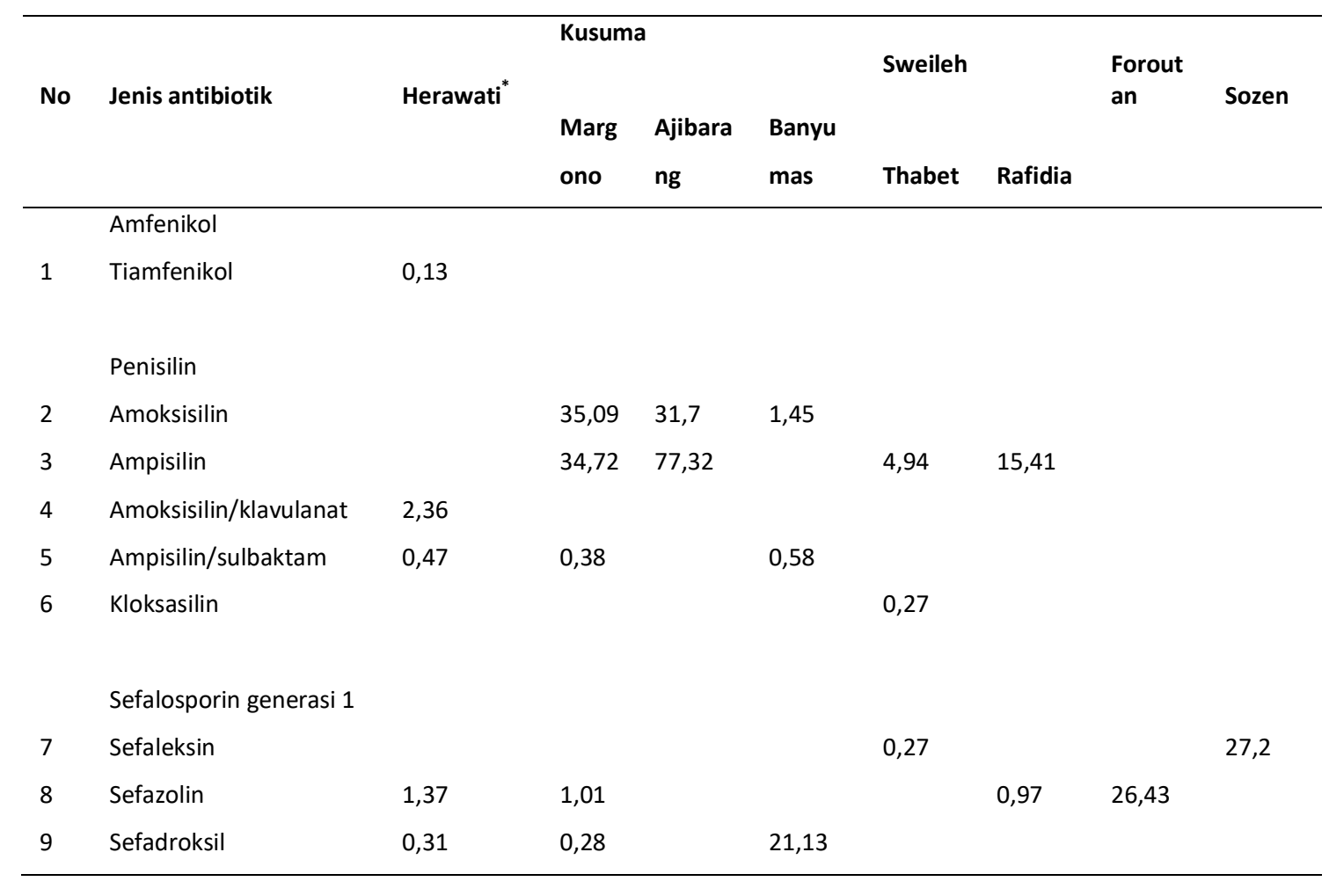


Sefalosporin generasi 2

10 Sefuroksim

0,28

0,69

40,48

36,17

2,7

Sefalosporin generasi 3

\begin{abstract}
11 Sefotaksim
\end{abstract}
0,09

0,57

0,52

16,89

0,38

12 Seftazidim

5,24

4,15

0,52

24,32

31,3

1,7

8,8
3,18

16 Sefoperazon/sulbaktam

0,93

6,02

Sefalosporin generasi 4

17 Sefepim

0,67

18 Sefpirom

0,02

Karbapenem

19 Meropenem

2,84

7,21

4,06

0,9

20 Imipenem/silastatin

1,02

0,17

Makrolida

21 Eritromisin

0,97

22 Azitromisin

0,04

Linkosamid

23 Klindamisin

1,36

Aminoglikosida

24 Gentamisin 0,53

0,03

25 Kanamisin

4,14

1,87

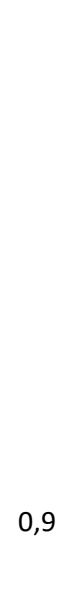

26 Amikasin
$10,15 \quad 11,35 \quad 2,5 \quad 5,9$ 


\begin{tabular}{|c|c|c|c|c|c|c|c|c|c|}
\hline \multicolumn{10}{|c|}{ Fluorokuinolon } \\
\hline 27 & Siprofloksasin & 1,01 & & & & \multicolumn{2}{|l|}{0,67} & 1,73 & 0,9 \\
\hline 28 & Levofloksasin & 1,8 & & & & & & & \\
\hline & \multicolumn{9}{|l|}{ Glikopeptida } \\
\hline 29 & Vankomisin & & & & & & \multicolumn{3}{|c|}{0,58} \\
\hline & \multicolumn{9}{|l|}{ Imidazol } \\
\hline 30 & Metronidazol & 3,4 & & & & 45,29 & 62,28 & 0,08 & 2,7 \\
\hline \multicolumn{10}{|c|}{ Total DDD/100 BD } \\
\hline & & 30,44 & 76,2 & 110,75 & 46,07 & 133,6 & 162,51 & 36,42 & 49,1 \\
\hline \multicolumn{2}{|c|}{ Total jenis antibiotik } & 24 & 7 & 5 & 5 & 9 & 8 & 9 & 7 \\
\hline
\end{tabular}

*satu rumah sakit

Tabel 5

Jumlah Penggunaan Antibiotik Dalam DDD/100 BD Dari Artikel yang Dipublikasi Di Jurnal Berkualitas Kurang Baik [11,13,15,17-19]

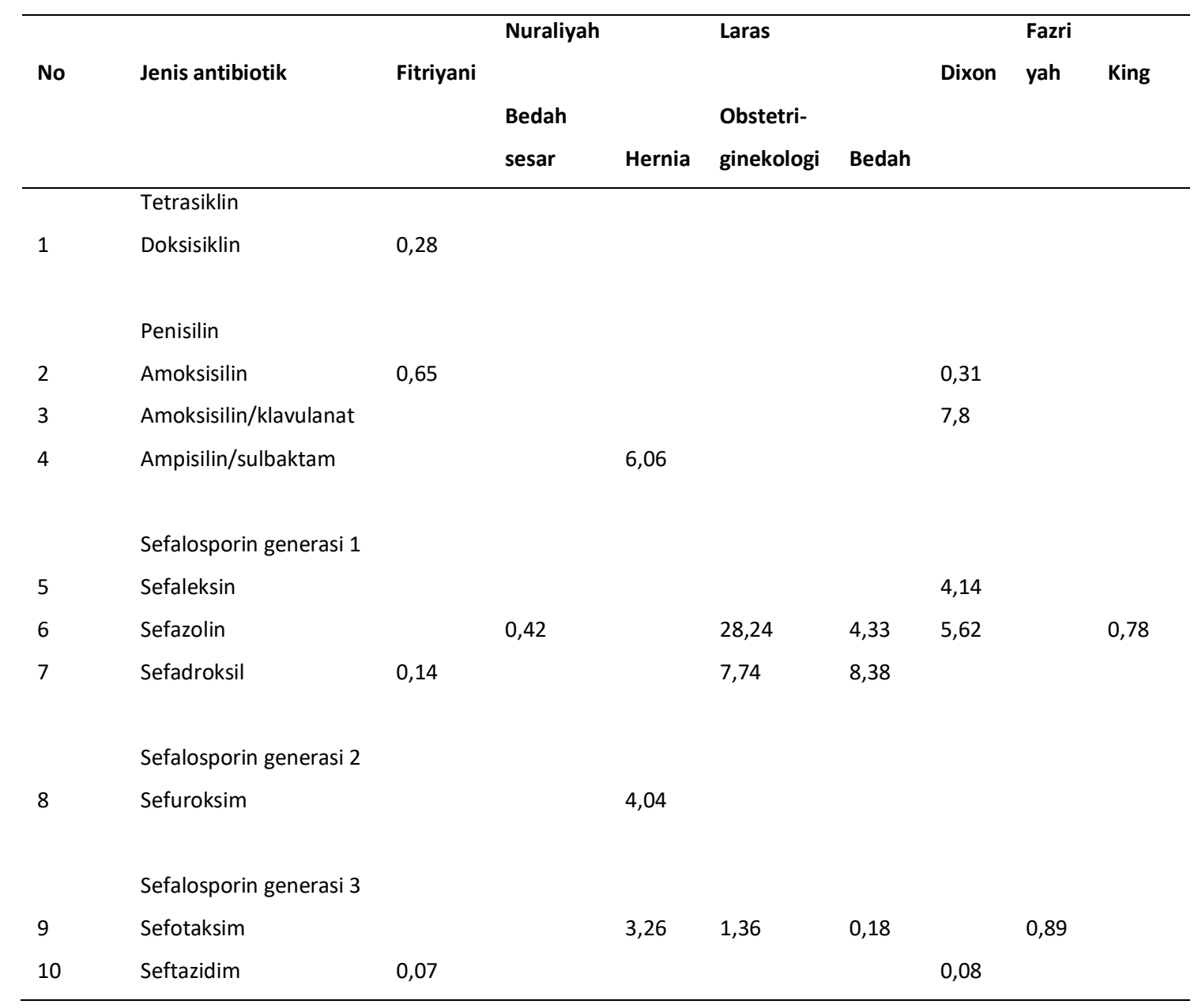




\begin{tabular}{|c|c|c|c|c|c|c|c|c|c|}
\hline & & & & & & & \multicolumn{3}{|c|}{46,5} \\
\hline 11 & Seftriakson & 20,21 & 62,58 & 32,95 & 5,67 & 36,88 & 4,12 & 2 & 11,18 \\
\hline 12 & Sefiksim & 4,78 & 21,38 & & & & & & \\
\hline \multirow[t]{2}{*}{13} & Sefoperazon/sulbaktam & & & 1,52 & & & & 2,43 & \\
\hline & Linkosamid & & & & & & & & \\
\hline \multirow[t]{2}{*}{14} & Klindamisin & & 0,94 & & & & 1,71 & & \\
\hline & Aminoglikosida & & & & & & & & \\
\hline 15 & Gentamisin & 0,09 & 0,84 & & 0,95 & 0,05 & 1,86 & & \\
\hline \multirow[t]{2}{*}{16} & Amikasin & & & & & & 7,98 & 1,59 & \\
\hline & Fluorokuinolon & & & & & & & & \\
\hline 17 & Siprofloksasin & & & & 0,66 & 0,66 & 2,78 & & \\
\hline \multirow[t]{2}{*}{18} & Levofloksasin & & & 2,27 & & & & & \\
\hline & Imidazol & & & & & & & & \\
\hline 19 & Metronidazol & & 7,55 & & 1,73 & 1,11 & & 5,57 & \\
\hline \multicolumn{2}{|c|}{ Total DDD/100 BD } & 26,22 & 93,71 & 50,1 & 46,35 & 51,59 & 36,4 & 57 & 11,96 \\
\hline \multicolumn{2}{|c|}{ Total jenis antibiotik } & 7 & 6 & 6 & 7 & 7 & 10 & 5 & 2 \\
\hline
\end{tabular}

\section{BAHASAN}

Penelitian ini dilakukan untuk mengevaluasi utilisasi antibiotik profilaksis untuk pasien bedah di Asia yang selama ini ditemukan masih bermasalah. Berdasarkan tabel hasil penelitian, masih ditemukan pemakaian antibiotik yang irasional (tidak sesuai guideline). WHO menyarankan penggunaan sefazolin atau sefuroksim sebagai pilihan utama antibiotik profilaksis untuk pasien bedah [6].

Laporan Joshi menunjukkan hal yang serupa dengan hasil penelitian yang ditemukan dalam penelitian ini , yaitu antibiotik golongan sefalosporin adalah jenis antibiotik yang paling sering diresepkan sebagai profilaksis dengan frekuensi peresepan $86 \%$ dan 38 dari 100 pasien mendapat injeksi seftriakson [20].

Laporan penelitian Akalin juga menunjukkan pemakaian yang irasional pada antibiotik seftriakson sebagai antibiotik profilaksis seperti yang ditemukan pada penelitian ini. Seftriakson merupakan antibiotik yang ketiga paling banyak digunakan setelah sefazolin dan kombinasi ampisilin/sulbaktam. Pemakaian seftriakson yang tinggi mungkin disebabkan karena seftriakson memiliki spektrum luas dengan toksisitas rendah [21] sehingga dokter memilih untuk meresepkan seftriakson meskipun WHO menyarankan penggunaan sefazolin atau sefuroksim [22].

Rentang total DDD/100 BD pada penelitian ini yaitu 11,96-162,2 DDD/100 BD hal ini menunjukkan bahwa DDD/100BD dari total antibiotik profilaksis di bangsal bedah masih bervariasi. Total DDD/100BD yang tinggi seperti pada penelitian Kusuma A.M. et al (2016) dan Sweileh W.M. et al (2012) mungkin disebabkan oleh peresepan antibiotik yang tidak dibutuhkan menurut guideline WHO atau perpanjangan dari pemberian profilaksis (antibiotik profilaksis yang diberikan setelah operasi selesai) [10,16].

Berdasarkan data yang sudah dijabarkan sebelumnya, penggunaan antibiotik yang tidak sesuai guideline/ irasional masih sering terjadi. Hal ini membuktikan bahwa pengawasan terhadap pemakaian antibiotik profilaksis di bangsal bedah perlu ditingkatkan untuk mencegah terjadinya pemakaian antibiotik yang irasional. 


\section{SIMPULAN}

Berdasarkan hasil penelitian, disimpulkan bahwa pengawasan terhadap pemakaian antibiotik profilaksis bangsal bedah masih perlu ditingkatkan. Hal ini bisa dilihat dari ketidaksesuaian terhadap rekomendasi internasional dan nilai DDD/100 Bed Days (BD) yang tinggi untuk antibiotik yang tidak disarankan dan pola penggunaan (jenis dan jumlah) yang bervariasi. Golongan cephalosporin merupakan golongan antibiotik yang paling sering digunakan khususnya ceftriaxone. Hal ini tidak sesuai dengan rekomendasi dari WHO yang menyarankan cefazoline atau cefuroxime. Selain itu, total DDD/100 BD yang masih beragam dengan rentang $11,96-162,2 \mathrm{DDD} / 100 \mathrm{BD}$. Total yang beragam juga menununjukkan variasi pola penggunaan antibiotik profilaksis di Asia.

Penelitian ini menunjukkan adanya variasi dan irasionalitas dari pemakaian antibiotik yang tidak menjadi pilihan utama. Perlu adanya guideline yang mengikuti saran dari WHO dan pola sensitivitas bakteri lokal di tiap rumah sakit serta memperketat pengawasan antibiotik untuk mengurangi pemakaian antibiotik yang irasional.

\section{Pembiayaan dan Konflik Kepentingan}

Peneliti tidak mendapat bantuan finansial dari pihak manapun dan tidak ada konflik dengan pihak lain.

\section{PUSTAKA ACUAN}

1. Aslam B, Wang W, Arshad MI, Khurshid M, Muzammil S, Rasool MH, Nisar MA, Alvi RF, Aslam MA, Qamar MU, Salamat MKF, Baloch Z. Antibiotic resistance: a rundown of a global crisis. Infect Drug Resist. 2018;11: 1645-58. https://doi.org/10.2147/IDR.S173867.

2. Robert JG. Combating antimicrobial resistance: policy recommendations to save lives. Clin Infect Dis. 2011;52(Suppl 5): S397-428. https://doi.org/10.1093/cid/cir153.

3. Ayele $\mathrm{Y}$, Taye $\mathrm{H}$. Antibiotic utilization pattern for surgical site infection prophylaxis at Dil Chora Referral Hospital Surgical Ward, Dire Dawa, Eastern Ethiopia. BMC Res Notes. 2018;11(1): 537. https://doi.org/10.1186/s13104-018-3629-6.

4. Herawati F, Yulia R, Hak E, Hartono AH, Michiels T, Woerdenbag HJ, Avanti CA. Retrospective surveillance of the antibiotics prophylactic use of surgical procedures in private hospitals in Indonesia. Hosp Pharm. 2019;54(5): 323-9. https://doi.org/10.1177/0018578718792804.

5. Mousavi S, Zamani E, Bahrami F. An audit of perioperative antimicrobial prophylaxis: compliance with the international guidelines. J Res Pharm Pract. 2017;6(2): 126-9. https://doi.org/10.4103/jrpp.JRPP_16_164.

6. The selection and use of essential medicines: report of the WHO Expert Committee on Selection and Use of Essential Medicines, 2019 (including the 21st WHO Model List of Essential Medicines and the 7th WHO Model List of Essential Medicines for Children). Geneva: World Health Organization; 2019. Available from: https://www.who.int/medicines/publications/essentialmedicines/UNEDITED_TRS_2019_E C22_Sept.pdf?ua=1.

7. Harrison R, Cohen AW, Walton M. Patient safety and quality of care in developing countries in Southeast Asia: a systematic literature review. Int J Qual Health Care. 2015;27(4): 240-54. https://doi.org/10.1093/intqhc/mzv041.

8. Versporten A, Zarb P, Caniaux I, Gros M, Drapier N, Miller M, Jarlier V, Nathwani D, Goossens H. Antimicrobial consumption and resistance in adult hospital inpatients in 53 countries: results of an internet-based global point prevalence survey. Lancet Glob Health. 2018;6(6): e619-29.

9. Moola S, Munn Z, Tufanaru C, Aromataris E, Sears K, Sfetcu R, Currie M, Qureshi R, Mattis P, Lisy K, Mu P-F. Chapter 7: Systematic reviews of etiology and risk . In: Aromataris E, Munn Z (Editors). Joanna Briggs Institute Reviewer's Manual. The Joanna Briggs Institute. 2017. Available from https://reviewersmanual.joannabriggs.org. 
10. Sweileh WM, Adas SO, Sawalha AF, Taha AS. Utilization and cost of antibacterial drugs in 2 general surgery units in Palestine measured using anatomical therapeutic chemical classification and defined daily dose methodology. East. Mediterr. Health J. 2012;18(6): 641-7. https://doi.org/10.26719/2012.18.6.641.

11. Laras NW, Farida H. Kuantitas penggunaan antibiotik di Bangsal Bedah dan Obstetriginekologi RSUP Dr. Kariadi setelah kampanye PP-PPRA. Jurnal Kedokteran Diponegoro. 2012;1(1): 112516.

12. Sözen H, Gönen I, Sözen A, Kutlucan A, Kalemci S, Sahan M. Application of ATC/DDD methodology to evaluate of antibiotic use in a general hospital in Turkey. Ann Clin Microbiol Antimicrob. 2013;12: 23. https://doi.org/10.1186/1476-0711-12-23.

13. Jeewan DTA, Alvarez-Uria G. DDDs per hundred bed days of antibiotics used for surgical prophylaxis in a rural resource limited secondary care Indian hospital. Healthcare Intervention Journal. 2013;1: 8-18. https://doi.org/10.13140/RG.2.2.21764.88965.

14. Foroutan B, Foroutan R. Perioperative antibiotic prophylaxis in elective surgeries in Iran. Med J Islam Repub Iran. 2014;28: 66.

15. King J, Ciptaningtyas VR. Kuantitas penggunaan antibiotik sebelum dan setelah pembuatan Pedoman Penggunaan Antibiotik (PPAB): penelitian pada kasus Bedah Digestif RSUP Dr. Kariadi Semarang. Media Medika Muda. 2015;4(4): 1072-82.

16. Kusuma AM, Galistiani GF, Wijayanti DN, Umami M, Nurdiyanti, Utaminingrum W, Sudarso. Evaluasi kuantitatif penggunaan antibiotik pada pasien caesarean section di RSUD se-Kabupaten Banyumas. Jurnal Farmasi Indonesia. 2016;8(1): 327-33.

17. Fazriyah N. Evaluasi penggunaan antibiotik profilaksis pada pasien Bedah Apendektomi dengan metode ATC/DDD dan DU 90\% di Rumah Sakit Umum Daerah Cengkareng periode Januari-Desember 2016 (Bachelor's thesis). UIN Syarif Hidayatullah Jakarta: Fakultas Kedokteran dan Ilmu Kesehatan. 2017.

18. Fitriyani, Ramadhan AM, Mahmudah F. Studi penggunaan antibiotik berdasarkan ATC/DDD pada pasien Bedah Orthopedi di RSUD Abdul Wahab Sjahranie Samarinda. Proceeding of the 8th Mulawarman Pharmaceuticals Conferences. 2018;8(1): 207-13. https://doi.org/10.25026/mpc.v8i1.325.

19. Nuraliyah NM, Ramadhania ZM, Syofiah E. Evaluasi penggunaan antibiotik pada pasien Bedah Caesar dan Hernia di salah satu rumah sakit di Jawa Barat. Majalah Farmasetika. 2019;4(5): 139-45. https://doi.org/10.24198/farmasetika.v4i5.23278.

20. Joshi DK, Rizwan M, Kothiyal P, Joshi Y. Evaluation of prescription pattern of antibiotics for surgical prophylaxis in secondary care hospital. Int J Basic Clin Pharmacol. 2017;6(8): 1969-76.

21. Sileshi A, Tenna A, Feyissa M, Shibeshi W. Evaluation of ceftriaxone utilization in medical and emergency wards of Tikur Anbessa specialized hospital: a prospective cross-sectional study. BMC Pharmacol Toxicol 17, 7 (2016). https://doi.org/10.1186/s40360-016-0057-x.

22. Akalin S, Kutlu SS, Cirak B, Eskiçorapcı SY, Bagdatli D, Akkaya S. Application of ATC/DDD methodology to evaluate perioperative antimicrobial prophylaxis. International Journal of Clinical Pharmacy. 2012;34(1): 120-6. https://doi.org/10.1007/s11096-011-9601-3. 